\title{
KAJIAN INDEKSASI
}

\section{Lies Kurnia Irwanti}

Email: emailnyalies@gmail.com

\section{PENDAHULUAN}

\subsection{Latar Belakang}

$\begin{array}{lrr} & \text { Undang-Undang Nomor } 17 & \text { Tahun } \\ 2003 \text { tentang Keuangan } & \text { Negara } \\ \text { mengamanatkan tiga pilar } & \text { sistem } \\ \text { penganggaran untuk penyusunan angaran } \\ \text { oleh Kementerian negara/Lembaga (K/L). } \\ \text { Ketiga pilar dimaksud yaitu penganggaran } \\ \text { terpadu, Penganggaran Berbasis } & \text { Kinerja } \\ \text { (PBK) dan Kerangka Pengeluaran Jangka } \\ \begin{array}{lrr}\text { Menengah } & \text { (KPJM). KPJM } & \text { adalah } \\ \text { pendekatan } & \text { penyusunan } & \text { anggran } \\ \text { berdasarkan } & \text { kebijakan, } & \text { dengan } \\ \text { pengambilan } & \text { keputusan } & \text { yang }\end{array}\end{array}$
menimbulkan implikasi anggaran dalam jangka waktu lebih dari satu tahun anggaran. Sesuai dengan amanat UU No 17 Tahun 2003, dalam penerapan KPJM, K/L menyusun prakiraan maju dalam periode tiga tahun ke depan. Hal tersebut merupakan keharusan yang dilakukan setiap tahun, bersamaan dengan penyampaian RKA-K/L.

Sejalan dengan hal tersebut, Peraturan Menteri Keuangan Nomor 71/PMK.02/2013 tentang Pedoman Standar Biaya, Standar Struktur Biaya, dan Indeksasi dalam Penyusunan Rencana Kerja dan Anggaran Kementerian Negara/Lembaga, Indeksasi didefinisikan sebagai parameter penyesuaian yang digunakan untuk menghitung kebutuhan alokasi biaya tahun yang direncanakan dan prakiranaan maju tahun anggaran berikutnya yang ditetapkan oleh Menteri
Keuangan. Penerapan indeksasi KPJM dalam kerangka teknik pembiayaan pada hakekatnya merupakan aspek mikro dari penerapan penganggaran yang melebihi dari satu tahun(KPJM). Penganggaran dengan KPJM dimaksud dilaksanakan dengan menggunakan konsep anggaran bergulir yang dilakukan dengan tiga instrumen yaitu baseline, new initiative dan parameter. Angka indeksasi pada hakekatnya merupakan angka parameter yang merujuk pada angka perkiraan inflasi di tahun yang direncanakan $\left(t_{1}, t_{2}, t_{3}\right)$ yang dilakukan penyesuaian merujuk kebijakan atas sebuah output. Pembiayaan dengan konsep indeksasi KPJM dimaksudkan untuk memperbaiki kualitas prakiraan maju agar sejalan prakiraan kebutuhan anggaran, pada saat perencanaan pembiayaan atas sebuah output.

Selanjutnya penerpan KPJM dilakukan dengan penggunaan prakiraan maju dalam RKA-K/L yang dilakukan dengan indeks. Proses pendisiplinan penerapan indeksasi KPJM pada hakekatnya merupakan bagian dari pembiayaan atas suatu output yang dalam KPJM dilakukan dengan merujuk pada konsep baseline dan new initiative. Indeksasi dilakukan untuk pembuatan prakiraan maju (prakiraan kebutuhan pembiayaan) dari suatu output merujuk pada klasifikasi dan jenis biaya dari suatu output. Jenis output yang dimaksudkan yaitu Indeks Keluaran (Output) barang infrastruktur, Indeks Keluaran (Output) 
barang non infrastruktur, Indeks Keluaran (Output) jasa regulasi dan Indeks Keluaran (Output) jasa layanan nonregulasi.Berkenaan dengan kebijakan tersebut, tulisan ini mencoba mendokumentasikan bagaimana sebuah angka indeks KPJM diformulasikan untuk kepentingan reviu baseline dan angka penyesuai sebagaimana dimaksudkan dalam PMK Nomor 71 Tahun 2013.

\subsection{Pertanyaan Penelitian}

Pada kajian ini akan menyajikan pendokumentasian penentuan angka indeks KPJM dengan menjawab beberapa pertanyaan berikut ini:

1. Bagaimana metode untuk memformulasikan angka indeksasi? dan

2. Berapa angka indeksasi untuk beberapa jenis output pada RKA-K/L 2018 ?

\subsection{Tujuan Penelitian}

Penelitian yang dilakukan dalam kajian ini bertujuan:

1. Menjelaskan metode yang digunakan untuk memformulasikan angka indeksasi, dan

2. Menentukan angka indeksasi untuk beberapa jenis output pada RKA-K/L 2018.

\subsection{Pembatasan Masalah}

Pada penelitian ini karena keterbatasan peneliti, maka formulasi perumusan indeksasi menggunakan hasil yang telah disusun oleh akademisi, yaitu Dr. Ir. Uka Wikarya, M.Si.

\section{LANDASAN TEORI}

\subsection{Rencana Kerja dan Anggaran} Kementerian Negara/Lembaga (RKA$\mathrm{K} / \mathrm{L})$

Rencana Kerja dan Anggaran Kementerian Negara/Lembaga (RKA-K/L) adalah dokumen rencana keuangan tahunan $\mathrm{K} / \mathrm{L}$ yang disusun menurut bagian anggaran K/L. Penyusunan anggaran dalam dokumen RKA-K/L merupakan bagian dari penyusunan Anggaran Pendapatan dan Belanja Negara (APBN), selain Rencana Dana Pengeluaran Bendahara Umum Negara (RDP-BUN). Secara garis besar, proses penyusunan RKA-K/L mengatur tiga materi pokok, yaitu pendekatan penyusunan anggaran, klasifikasi anggaran dan proses penganggaran.

\subsubsection{Penganggaran Berbasis Kinerja (PBK)}

Sesuai dengan amanat UndangUndang Nomor 17 Tahun 2003 tentang Keuangan Negara, penyusunan anggaran oleh $\mathrm{K} / \mathrm{L}$ mengacu kepada tiga pilar sistem penganggaran, yaitu: Pendekatan Penganggaran Terpadu, Penganggaran Berbasis Kinerja (PBK), dan Kerangka Pengeluaran Jangka Menengah (KPJM).Pendekatan penyusunan anggaran tersebut terus mengalami perbaikan dan penyempurnaan, dan diwajibkan menjadi acuan bagi pemangku kepentingan bidang penganggaran dalam merancang dan menyusun anggaran.

PBK merupakan suatu pendekatan dalam sistem penganggaran yang memperhatikan keterkaitan antara pendanaan dan kinerja yang diharapkan, serta memperhatikan efisiensi dalam 
pencapaian kinerja tersebut. Kinerja merupakan prestasi kerja yang berupa keluaran (output) dari suatu kegiatan atau hasil dari suatu program dengan kuantitas dan kualitas yang terukur. Agar penerapan PBK dapat dioperasionalkan, PBK menggunakan instrumen, sebagai berikut:

1. indikator kinerja, merupakan instrumen yang digunakan untuk mengukur kinerja,

2. standar biaya, adalah satuan biaya yang ditetapkan baik berupa standar biaya masukan dan standar biaya keluaran maupun standar struktur biaya sebagai acuan perhitungan kebutuhan anggaran, dan

3. evaluasi kinerja, merupakan penilaian terhadap capaian sasaran kinerja, konsistensi perencanaan dan implementasi, serta realisasi penyerapan anggaran.

\subsubsection{Kebijakan Indeksasi Sebagai Bagian Standar Biaya}

Pelaksanaan reformasi penganggaran berdasarkan UU Nomor 17 Tahun 2003 tentang Keuangan Negara perlu dijaga konsistensi dan kelanjutannya untuk menjamin terwujudnya penganggaran yang efektif dan efesien. Sejalan telah ditetapkannya PP Nomor 90 Tahun 2010 tentang RKA-K/L sebagai revisi PP 21 Tahun 2004 perlu dilakukan pemantapan penerapan Penganggaran Berbasis Kinerja (PBK). Revisi PP dimaksud diantaranya dilatarbelakangi oleh perlunya penguatan tentang konsep anggaran bergulir, penerapan parameter serta penambahan ketentuan tentang pengukuran dan evaluasi kinerja. Standar biaya merupakan instrumen dalam penyusunan $\mathrm{RKA}-\mathrm{K} / \mathrm{L}$, dimana bersama dengan dua instrumen PBK lainnya, yaitu indikator kinerja dan evaluasi kinerja, digunakan pemerintah dalam pengelolaan APBN.

Pada Pasal 5 ayat (3) PP Nomor 90 Tahun 2010 tentang Penyusunan Rencana Kerja dan Anggaran Kementerian/Lembaga:

"Penyusunan RKA-K/L menggunakan instrumen indikator kinerja, standar biaya dan evaluasi kinerja"

Amanat PMK No. 71/PMK.02/2013 tentang Pedoman Standar Biaya, Standar Struktur Biaya, dan Indeksasi dalam Penyusunan Rencana Kerja dan Anggaran Kementerian Negara/Lembaga Pasal 26 bahwa:

"dalam rangka mendukung efisiensi alokasi biaya dalam penyusunan RKA-K/L, Menteri Keuangan menetapkan Standar Struktur Biaya dan Indeksasi."

Indeksasi sendiri didefinisikan dalam PMK Nomor 71 Tahun 2013 dalam Pasal 28 yaitu "indeksasi merupakan alat yang digunakan untuk penghitungan kebutuhan anggaran dalam kerangka pengeluaran jangka menengah." Indeksasi digunakan oleh $\mathrm{K} / \mathrm{L}$ untuk menyusun penghitungan anggaran dasar (baseline) dan inisiatif baru. Penggunaan indeksasi dalam penghitungan anggaran dasar dilakukan untuk menyesuaikan perhitungan kebutuhan besaran biaya keluaran (output) pada tahun anggaran yang direncanakan dan prakiraan maju tahun anggaran berikutnya.

\subsection{Indeksasi}

Penerapan indeksasi KPJM dalam kerangka costing (teknik perhitungan 
biaya) merupakan aspek mikro dari penerapan penganggaran yang melebihi satu tahun anggaran dengan menggunakan konsep anggaran bergulir. Konsep anggaran bergulir tersebut dilaksanakan dengan tiga instrumen, yaitu anggaran dasar (baseline), inisiatif baru dan parameter. Angka indeksasi merupakan angka parameter yang merujuk antara lain pada angka perkiraan besaran inflasi dan kurs di tahun yang direncanakan $\left(t_{1}, t_{2}, t_{3}\right)$. Angka indeksasi tersebut disusun sesuai klasifikasi output dan jenis biaya atas sebuah output. Indeksasi KPJM digunakan untuk menyusun prakiraan maju/pagu kebutuhan alokasi biaya suatu dasar keluaran (output baseline) dan inisiatif baru pada tahun anggaran yang direncanakan.

Fungsi utama indeksasi dalam rangka perencanaan anggaran berupa:

1. Penghitungan pagu kebutuhan alokasi biaya suatu output pada tahun anggaran yang direncanakan bagi dasar output baseline.

2. Penghitungan prakiraan maju tahun anggaran berikutnya bagi output baseline dan insiatif baru.

Biaya atas suatu keluaran (output) terdiri dari biaya utama dan biaya pendukung. Biaya utama merupakan komponen pembiayaan langsung dari pelaksanaan langsung dari pelaksanaan suatu kebijakan dan berpengaruh terhadap pencapaian keluaran (output). Sedangkan biaya pendukung (penunjang) merupakan komponen pembiayaan yang digunakan dalam rangka menjalankan dan mengelola kebijakan.
Penetapan nilai indeksuntuk output dalam RKA-K/L, dikelompokkan sebagai berikut:

1. Keluaran (output) Barang, yang terdiri dari:

a. Output barang infrastruktur, yaitu output kegiatan yang merupakan barang berwujud dan atau berupa jaringan yang diperlukan untuk jaminan ekonomi sektor publik agar perekonomian dapat berfungsi dengan baik. Contoh: jalan, kereta api, air bersih, bandara, kanal, waduk, pengolahan limbah, dan sebagainya.

b. Output barang non infrastruktur, yaitu output kegiatan yang merupakan barang baik berwujud maupun tidak berwujud yang tidak berupa jaringan yang bukan termasuk barang infrastruktur. Contoh: kendaraan, software aplikasi, dan sebagainya.

2. Keluaran (output) Jasa, yang terdiri dari:

a. Output jasa regulasi/birokrasi, yaitu output yang dihasilkan dari suatu kegiatan dalam rangka pembuatan peraturan atau pendukung administrasi birokrasi. Bentuk output tersebut dapat berupa norma, standar, dan lain-lain.

b. Output jasa layanan non-regulasi, yaitu output dari suatu kegiatan yang merupakan layanan dari suatu instansi pemerintah. Contoh: SP2D, layanan BOS, dan sebagainya.

Penerapan indeksasi dilakukan dengan tujuan dapat menghasilkan perhitungan angka prakiraan maju yang mencerminkan kebutuhan riil pada saat pelaksanaannya.Dalam pendekatan KPJM disampaikan bahwa proyeksi biaya output 
pada tahun direncanakan disesuaikan dengan angka indeks, dengan rumusan:

output $=h \arg a \times$ kuantitas $\times$ indeks

Jenis dan besarannya indeks yang akan ditetapkan terdiri atas:

1. Indeks untuk kebutuhan output layanan perkantoran belanja pegawai.

2. Indeks untuk kebutuhan output layanan perkantoran belanja barang.

3. Indeks untuk komponen utama output barang infrastuktur.

4. Indeks untuk komponen utama output barang non-infrastruktur.

5. Indeks untuk komponen utama output jasa regulasi.

6. Indeks untuk komponen utama output jasa layanan non-regulasi.

7. Indeks untuk komponen pendukung output barang infrastruktur.

8. Indeks untuk komponen pendukung output barang non-infrastruktur.

9. Indeks untuk komponen pendukung output jasa regulasi.

10. Indeks untuk komponen pendukung output jasa layanan non-regulasi.

\subsection{Indeks Harga Konsumen (IHK)}

Inflasi merupakan suatu keadaan perekonomian yang menunjukkan adanya kecenderungan kenaikan tingkat harga secara umum. Dikatakan tingkat harga umum karena barang dan jasa yang ada di pasaran memiliki jenis dan jumlah yang beraneka ragam. Sebagian besar dari harga-harga barang tersebut selalu meningkat dan mengakibatkan terjadinya inflasi. Beberapa faktor penyebab inflasi, yaitu:

1. demand inflation, merupakan inflasi yang timbul karena meningkatnya permintaan masyarakat terhadap barang dan jasa.

2. cost inflation yaitu inflasi yang timbul naiknya biaya produksi untuk menghasilkan barang dan jasa.

3. imported inflation, yaitu inflasi yang timbul karena kenaikan harga barang impor yang digunakan sebagai baham mentah produksi di dalam negeri.

4. teori kuantitas yaitu pertambahan jumlah uang yang beredar di masyarakat, baik uang kartal maupun uang giral dan alat pembayaran lainnya.

Indeks harga adalah salah satu indikator ekonomi yang secara umum dapat menggambarkan tingkat inflasi/deflasi harga barang dan jasa. Indeks harga merupakan sebuah rataan dari perubahan harga yang proporsional pada suatu barang atau jasa tertentu antara dua periode waktu. Indeks harga biasa digunakan untuk mengetahui ukuran perubahan variabel-variabel ekonomi sebagai barometer keadaan perekonomian. Indeks hargadi Indonesia dihitung dengan mengembangkan metode agregatif tertimbang, yaitu metode Laspeyres, metode Paasche dan metode tahun khas. Beberapa macam indeks harga yaitu:

1. Indeks Harga Konsumen (IHK) adalah angka yang menggambarkan perbandingan perubahan harga barang dan jasa yang dihitung dianggap mewakili belanja konsumen, kelompok barang yang dihitung bisa berubah-ubah disesuaikan dengan pola konsumsi aktual masyarakat.

2. Indeks Harga Produsen (IHP) adalah perbandingan perubahan barang dan jasa yang dibeli oleh produsen pada 
waktu tertentu, yang dibeli oleh produsen meliputi bahan mentah dan bahan setengah jadi. Perbedaannya dengan IHK adalah kalau IHP mengukur tingkat harga pada awal sistem distribusi, IHK mengukur harga langsung yang dibayar oleh konsumen pada tingkat harga eceran. Indeks harga produsen biasa disebut juga indeks harga grosir.

3. Indeks harga yang harus dibayar dan diterima oleh petani. Indeks harga barang-barang yang dibayar oleh petani baik untuk biaya hidup maupun untuk biaya proses produksi, apabila dalam menghitung indeks dimasukkan unsur jumlah biaya hipotek, pajak, upah pekerja yang dibayar oleh petani, indeks yang diperoleh disebut indeks paritas. Rasio antara indeks harga yang harus dibayar oleh petani dengan indeks paritas dalam waktu tertentu disebut rasio paritas.

Komoditas barang dan jasa yang dipilih dalam perhitungan IHK didasarkan pada Survei Biaya Hidup (SBH) yangdilakukan oleh Badan Pusat Statistik (BPS). Barang dan jasa yang dipilih untuk disurvei diklasifikasikan menjadi 7 kelompok pengeluaran rumah tangga, yaitu:

1. bahan makanan,

2. makanan jadi, minuman, rokok, dan tembakau,

3. perumahan, air, listrik, gas, dan bahan bakar,

4. sandang,

5. kesehatan,

6. pendidikan, rekreasi, dan olahraga, serta

7. transpor, komunikasi, dan jasa keuangan.
Data harga barang dan jasa yang dikumpulkan adalah harga di tingkat pedagang eceran dan merupakan harga transaksi. Observasi harga dilakukan secara harian, mingguan, dua mingguan dan bulanan. Dari setiap kota, data harga dikumpulkan pada beberapa pasar tradisional maupun pasar modern yang mewakili harga di kota tersebut. Data dari masing-masing komoditas diperoleh dari 3 atau 4 outlet dan dikumpulkan langsung dari pemantauan harga.

\section{METODOLOGI PENELITIAN}

\subsection{Jenis Penelitian}

Penelitian ini adalah penelitian deskriptif yang menggunakan pendekatan kuantitatif.

\subsection{Objek Penelitian}

Objek penelitian adalah data faktor-faktor penyebab Indeks Harga Konsumen (IHK).

\subsection{Jenis Data}

Data merupakan kumpulan informasi yang diperoleh dari suatu pengamatan, dapat berupa angka, lambang atau sifat. Data yang digunakan merupakan data sekunder, yaitu data yang diperoleh dari laman Badan Pusat Statistik.

\subsection{Metode Pengolahan Data}

Pada kajian ini pada prinsipnya ingin mengetahui berapa angka indeksasi untuk tahun anggaran 2018. Untuk menentukan angka indeksasi tersebut dilakukan dengan proyeksi inflasi melalui pendekatan ekonometri. Setelah itu angka inflasi dijabarkan untuk menjadi indeks 
dari sepuluh jenis output menggunakan regresi dan solver. Dalam kajian ini data yang diperoleh diolah menggunakan bantuan perangkat lunak eviews, minitab, dan microsoft excel.

\section{PEMBAHASAN}

\subsection{Pemutakhiran Data Faktor Penyebab Inflasi}

Inflasi dapat disebabkan oleh beberapa faktor. Pada penelitian ini faktorfaktor yang menyebabkan inflasi dinamakan variabel independen, sedangkan untuk inflasinya sendiri dinamakan variabel dependen. Dalam rangka untuk mendapatkan angka indeksasi yang akan digunakan pada tahun anggaran 2018, akan dilakukan terlebih dahulu proyeksi inflasi dengan pendekatan ekonometri. Model untuk memproyeksikan inflasi diperoleh dari hasil penelitian yang dilakukan oleh Dr. Ir. Uka Wikarya, M.Si. menggunakan model panel dengan data historis tahun 20072011, model dimaksud yaitu:

$$
\begin{aligned}
& \log \left(C P I_{i t}\right)=\alpha_{i}+\beta_{1} \log \left(M 1_{t}\right)+ \\
& \beta_{2} \log \left(N E R_{t}\right)+\beta_{3} \log \left(P B B M_{t}\right)+ \\
& \beta_{4} \log \left(G A J I P N S_{t}\right)+\beta_{5} \log \left(\text { PElect }_{t}\right)+ \\
& \gamma_{i} \log \left(\text { CONS }_{i t}+I N V_{i t}+G C_{i t}\right)+\varepsilon_{i}
\end{aligned}
$$

dengan keterangan untuk setiap variabel, sebagai berikut:

1. CPI (Consumer Price Index): indeks harga konsumen di provinsi

2. M1: jumlah uang beredar

3. NER (Nominal Exchange Rate): nilai tukar rupiah terhadap dollar

4. PBBM: harga rata-rata BBM premium dan solar

5. GAJIPNS: gaji pokok rata-rata PNS Golongan IIIa
6. PElect: harga listrik rata-rata

7. CONS: PDRB konsumsi rumah tangga atas dasar harga konstan 2000

8. INV: PDRB pembentukan modal tetap atas dasar harga konstan 2000

9. GC: PDRB pengeluaran konsumsi pemerintah atas dasar harga konstan 2000

Berdasarkan model yang diperoleh tersebut, dilakukan simulasi dengan bantuan perangkat lunak eviews. Data yang diperlukan untuk simulasi merupakan data runtun waktu dari tahun 2011 hingga 2020. Akan tetapi, saat ini sedang berjalan di tahun 2016, sehingga untuk data dari tahun 2017 hingga 2020 diperoleh dari hasil peramalan (forecasting). Metode peramalan yang digunakan dalam penelitian ini yaitu exponential smoothing yang merupakan salah satu analisis deret waktu dan merupakan metode peramalan dengan memberi nilai pembobot pada serangkaian pengamatan sebelumnya untuk memprediksi nilai masa depan (Trihendradi, 2005).Peramalan yang dilakukan untuk meng-update data dibantu perangkat lunak minitab.Datadata yang di-update untuk digunakan dalam simulasi, yaitu:

1. Data nilai tukar rupiah terhadap dollar. Data yang digunakan yaitu data bulanan dari tahun 2001 hingga tahun 2016, kemudian hasil peramalannya untuk bulan Desember 2016. Selanjutnya yang dimasukkan dalam simulasi adalah rata-rata di tahun 2016.

2. Data tarif listrik rata-rata (rupiah per KWH). Data yang digunakan adalah data tarif listrik bulanan yang kemudian dirata-rata untuk mendapatkan data tahunan. 
3. Kenaikan gaji PNS (dalam \%). Terkait kebijakan pemerintah sejak tahun 2016 tidak terdapat kenaikan gaji PNS, maka untuk update data kenaikan gaji PNS diisi $0 \%$.

4. Jumlah uang beredar. Untuk data tahun 2016, diramalkan dulu jumlah uang beredar untuk bulan Desember 2016, karena data yang tersedia dari BPS adalah data bulanan. Setelah didapatkan data bulan Desember 2016, selanjutnya dirata-rata selama tahun 2016 untuk meng-update data M1 di tahun 2016 untuk simulasi.
5. Rata-rata harga BBM transportasi bersubsidi. Data yang digunakan yaitu data terkini harga premium dan solar di tahun 2016 kemudian dirata-rata.

Data yang telah di-update tersebut kemudian dijalankan program simulasi yang telah dibuat oleh Dr. Ir. Uka Wikarya, M.Si. dengan kombinasi bantuan perangkat lunak microsoft excel dan eviews. Data asumsi faktor penyebab inflasi yang telah di-update tersaji seperti dalam tabel berikut.

Tabel 4.1 Data Asumsi Faktor Penyebab Inflasi

$\begin{array}{crrcrr}\text { Tahun } & \text { Nilai Tukar } & \text { Tarif Listrik } & \text { Gaji PNS (\%) } & \text { Uang Beredar } & \text { BBM } \\ 2011 & 8.776 & 700 & 10 & 634.788 & 4.500 \\ 2012 & 9.384 & 725 & 10 & 758.404 & 4.500 \\ 2013 & 10.459 & 798 & 6 & 842.934 & 6.065 \\ 2014 & 11.869 & 1.528 & 6 & 905.441 & 8.138 \\ 2015 & 13.389 & 1.506 & 6 & 999.281 & 7.255 \\ 2016 & 13.277 & 1.402 & 0 & 1.113 .999 & 6.079 \\ 2017 & 13.428 & 1.536 & 0 & 1.207 .058 & 6.021 \\ 2018 & 13.857 & 1.632 & 0 & 1.298 .355 & 6.256 \\ 2019 & 14.285 & 1.729 & 0 & 1.389 .651 & 6.490 \\ 2020 & 14.713 & 1.826 & 3 & 1.480 .947 & 6.724\end{array}$

\subsection{Angka Proyeksi Inflasi dan Indeksasi}

Indeks harga merupakan salah satu indikator ekonomi yang secara umum dapat menggambarkan tingkat inflasi harga barang dan jasa. Oleh karena itu, angka proyeksi inflasi yang diperoleh dari hasil simulasi akan dijabarkan menjadi angka indeks untuk kesepeuluh jenis output yang ada di dalam RKA-K/L guna menjadi baseline.

Angka proyeksi inflasi yang diperoleh dari hasil simulasi untuk tahun 2018 yaitu 4,13\%. Sebagai pembanding, pada sasaran inflasi untuk tahun 2018 yang ditetapkan melalui PMK Nomor93/PMK.011/2014 adalah sebesar $3,5 \%$ dengan deviasi sebesar $1 \%$. Angka proyeksi inflasi tersebut dijabarkan pada komponen-komponen yang membentuk angka inflasi global untuk tahun yang akan diproyeksikan (2018). Langkah-langkah menjabarkan ke dalam tujuh komponen, sebagai berikut:

1. Ambil data realisasi rincian inflasi per kategori barang menurut kelompok pengeluaran selama 10 tahun terakhir, yaitu: 
Tabel 4.2 Data Inflasi Menurut Kelompok Pengeluaran

\begin{tabular}{|r|r|r|r|r|r|r|r|r|}
\hline Tahun & $\begin{array}{c}\text { Bahan } \\
\text { Makanan }\end{array}$ & $\begin{array}{c}\text { Madi, } \\
\text { Minuman, } \\
\text { Rokok, dan } \\
\text { Tembakau }\end{array}$ & $\begin{array}{c}\text { Perumahan, } \\
\text { Air, Listrik, } \\
\text { Gas, dan } \\
\text { Bahan Bakar }\end{array}$ & Sandang & Kesehatan & $\begin{array}{c}\text { Pendidikan, } \\
\text { Rekreasi } \\
\text { dan } \\
\text { Olahraga }\end{array}$ & $\begin{array}{c}\text { Transpor, } \\
\text { Komunikasi, } \\
\text { dan Jasa } \\
\text { Keuangan }\end{array}$ & Umum \\
\hline 2016 & 5,17 & 4,90 & 1,72 & 3,53 & 3,58 & 2,68 & $-1,82$ & 2,59 \\
2015 & 4,93 & 6,42 & 3,34 & 3,43 & 5,32 & 3,97 & $-1,53$ & 3,35 \\
\hline 2014 & 10,57 & 8,11 & 7,36 & 3,08 & 5,71 & 4,44 & 12,14 & 8,36 \\
2013 & 11,35 & 7,45 & 6,22 & 0,52 & 3,70 & 3,91 & 15,36 & 8,38 \\
2012 & 5,68 & 6,11 & 3,35 & 4,67 & 2,91 & 4,21 & 2,20 & 4,30 \\
2011 & 3,64 & 4,51 & 3,47 & 7,57 & 4,26 & 5,16 & 1,92 & 3,79 \\
\hline 2010 & 15,64 & 6,96 & 4,08 & 6,51 & 2,19 & 3,29 & 2,69 & 6,96 \\
\hline 2009 & 3,88 & 7,81 & 1,83 & 6,00 & 3,89 & 3,89 & $-3,67$ & 2,78 \\
2008 & 16,35 & 12,53 & 10,92 & 7,33 & 7,96 & 6,66 & 7,49 & 11,06 \\
2007 & 11,26 & 6,41 & 4,88 & 8,42 & 4,31 & 8,83 & 1,25 & 6,59 \\
\hline
\end{tabular}

Sumber: BPS, 2016

2. Estimasikan koefisien yang menjadi bobot dari masing-masing komponen menggunakan program microsoft excel dengan memilih menu "data analysis", "regression" selanjutnya masukkan variabel dependen di kolom $\mathrm{y}$ dan variabel independen di kolom $\mathrm{x}$.

Tabel 4.3 Koefisien Regresi Setiap

\begin{tabular}{|r|r|r}
\multicolumn{3}{c}{ Variabel } \\
\hline & Coefficients & Standard Error \\
\hline Intercept & 0,009667984 & 0,146960465 \\
\cline { 1 - 1 } X Variable 1 & 0,221371715 & 0,00941045 \\
\cline { 1 - 1 } X Variable 2 & 0,162419423 & 0,017175724 \\
\cline { 1 - 1 } X Variable 3 & 0,297458447 & 0,047206679 \\
\hline X Variable 4 & 0,064860965 & 0,015004597 \\
\cline { 1 - 1 } X Variable 5 & $-0,0344791$ & 0,038677624 \\
\cline { 1 - 1 } X Variable 6 & 0,111752692 & 0,014645502 \\
\cline { 1 - 1 } X Variable 7 & 0,161646792 & 0,011229772 \\
\hline
\end{tabular}

3. Estimasikan nilai inflasi dari setiap komponen dengan nilai proyeksi inflasi. Hal ini dilakukan dengan bantuan microsoft excel pada menu "data" kemudian "solver" dan masukkan "value of" sesuai dengan angka proyeksi inflasi yaitu 4,13 kemudian klik "solve".

Tabel 4.4 Nilai Proyeksi Inflasi Tiap Komponen di Tahun 2018

\begin{tabular}{|c|c|c|c|c|}
\hline Cell & Name & Original Value & Final Value & Integer \\
\hline \$0\$17 & Bahan Makanan & 4,412960999 & 4,412960999 & 9 Contin \\
\hline$\$ 0 \$ 18$ & Makanan Jadi, Minuman, Rokok, dan Tembakau & 3,237769543 & 3,237769543 & 3 Contin \\
\hline$\$ 0 \$ 19$ & Perumahan, Air, Listrik, Gas, dan Bahan Bakar & 5,92972107 & 5,92972107 & 7 Contin \\
\hline$\$ 0 \$ 20$ & Sandang & 1,292978659 & 1,292978659 & 9 Contin \\
\hline$\$ 0 \$ 21$ & Kesehatan & 0 & & 0 Contin \\
\hline$\$ 0 \$ 22$ & Pendidikan, Rekreasi dan Olahraga & 2,227747425 & 2,227747425 & 5 Contin \\
\hline$\$ 0 \$ 23$ & Transpor, Komunikasi, dan Jasa Keua & 3,222367553 & 3,222367553 & 3 Contin \\
\hline
\end{tabular}


4. Besaran indeks ditetapkan dalam penghitungan prakiraan maju pada output:

a. Indeks Keluaran (Output) barang infrastruktur;

b. Indeks Keluaran (Output) barang non infrastruktur;

c. Indeks Keluaran (Output) jasa regulasi; dan

d. Indeks Keluaran (Output) jasa layanan non-regulasi.
5. Nilai indeksasi tiap komponen dimasukkan dalam tabel per output dan koefisien regresi yang didapatkan dijadikan sebagai bobot. Nilai indeks untuk setiap komponen diperoleh dari hasil perkalian bobot dengan estimasi nilai inflasi tiap komponen di tahun 2018, kemudian ditambahkan konstanta. Untuk lebih jelasnya disajikan dalam tabel berikut:

Tabel 4.5 Jenis Output dan Bobot Tiap Komponen

\begin{tabular}{|c|c|c|c|c|c|c|c|}
\hline \multirow{2}{*}{ Jenis Output } & \multicolumn{7}{|c|}{ Proporsi Komponen } \\
\hline & (1) & $(2)$ & (3) & (4) & (5) & (6) & (7) \\
\hline Layanan Perkantoran Belanja Pegawai & 0,221 & 0,162 & 0,297 & 0,065 & $-0,034$ & 0,112 & 0,162 \\
\hline Layanan Perkantoran Belanja Barang & 0,221 & 0,162 & 0,297 & 0,065 & - & 0,112 & 0,162 \\
\hline Komponen Utama Keluaran Barang Infrastruktur & - & & 0,700 & I & 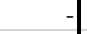 & & 0,300 \\
\hline Komponen Utama Keluaran Barang Non-Infrastruktur & - & 0,200 & 0,550 & & & & 0,250 \\
\hline Komponen Utama Keluaran Jasa Regulasi & 0,221 & 0,162 & 0,297 & 0,065 & $-0,034$ & 0,112 & 0,162 \\
\hline Komponen Utama Keluaran Jasa Non-Regulasi & 0,221 & 0,162 & 0,297 & 0,065 & $-0,034$ & 0,112 & 0,162 \\
\hline Komponen Pendukung Keluaran Barang Infrastruktur & 0,221 & 0,162 & 0,297 & 0,065 & $-0,034$ & 0,112 & 0,162 \\
\hline Komponen Pendukung Keluaran Barang Non-Infrastruktur & 0,221 & 0,162 & 0,297 & 0,065 & $-0,034$ & 0,112 & 0,162 \\
\hline Komponen Pendukung Keluaran Jasa Regulasi & 0,221 & 0,162 & 0,297 & 0,065 & $-0,034$ & 0,112 & 0,162 \\
\hline Komponen Pendukung Keluaran Jasa Non-Regulasi & 0,221 & 0,162 & 0,297 & 0,065 & $-0,034$ & 0,112 & 0,162 \\
\hline
\end{tabular}

6. Guna kebutuhan penyesuaian angka dasar (baseline) untuk tahun anggaran 2018, besaran indeksasi yang dapat disarankan, yaitu:

Tabel 4.6 Besaran Indeks untuk Tiap

\begin{tabular}{|l|r|}
\hline \multicolumn{1}{|c|}{ Jenis Output } & \multicolumn{1}{|c|}{ Indeks } \\
\hline Layanan Perkantoran Belanja Pegawai & 4,130 \\
\hline Layanan Perkantoran Belanja Barang & 4,130 \\
\hline Komponen Utama Keluaran Barang Infrastruktur & 5,127 \\
\hline Komponen Utama Keluaran Barang Non-Infrastruktur & 4,724 \\
\hline Komponen Utama Keluaran Jasa Regulasi & 4,130 \\
\hline Komponen Utama Keluaran Jasa Non-Regulasi & 4,130 \\
\hline Komponen Pendukung Keluaran Barang Infrastruktur & 4,130 \\
\hline Komponen Pendukung Keluaran Barang Non-Infrastruktur & 4,130 \\
\hline Komponen Pendukung Keluaran Jasa Regulasi & 4,130 \\
Komponen Pendukung Keluaran Jasa Non-Regulasi & 4,130 \\
\hline
\end{tabular}

Jenis Output

Berdasarkan hasil penjabaran nilai proyeksi inflasi telah diperoleh indeks untuk masing-masing jenis output. Beberapa jenis output memiliki nilai indeks melebihi nilai proyeksi inflasi, yaitu komponen utama output barang infrastruktur $(5,13)$ dan output barang non-infrastruktur $(4,72)$. Jenis output lainnya baik yang merupakan komponen utama dan pendukung memiliki nilai indeks sama dengan nilai proyeksi inflasi, yaitu 4,13.

\section{PENUTUP}

\subsection{Kesimpulan}

Berdasarkan kajian yang telah dilakukan, diperoleh kesimpulan sebagai berikut:

1. Indeksasi dilakukan untuk pembuatan prakiraan maju (prakiraan kebutuhan pembiayaan) dari suatu output merujuk pada klasifikasi dan jenis biaya dari suatu output. Nilai indeks yang diperolehakan digunakan untuk kepentingan reviu baseline dan angka 
penyesuai sebagaimana dimaksudkan dalam PMK Nomor 71 Tahun 2013.

2. Indeks harga merupakan salah satu indikator ekonomi yang secara umum dapat menggambarkan tingkat inflasi harga barang dan jasa. Oleh karena itu, dalam merumuskan indeksasi terlebih dahulu diproyeksikan nilai inflasi dengan menggunakan variabelvariabel penyebab inflasi.

3. Model yang digunakan untuk memproyeksikan inflasi, yaitu: $\log \left(C P I_{i t}\right)=\alpha_{i}+\beta_{1} \log \left(M 1_{t}\right)+$ $\beta_{2} \log \left(N E R_{t}\right)+\beta_{3} \log \left(P B B M_{t}\right)+$ $\beta_{4} \log \left(\right.$ GAJIPNS $\left._{t}\right)+\beta_{5} \log \left(\right.$ PElect $\left._{t}\right)$ $+\gamma_{i} \log \left(C O N S_{i t}+I N V_{i t}+G C_{i t}\right)+\varepsilon_{i}$ Dari model dimaksud, diperoleh angka proyeksi inflasi untuk 2018 sebesar $4,13 \%$.

4. Untuk dapat digunakan sebagai angka indeksasi, nilai proyeksi inflasi dijabarkan lebih lanjut dengan menggunakan regresi dan solver di microsoft excel.

5. Angka indeksasi untuk masing-masing jenis output diperoleh seperti pada tabel 4.6.

\subsection{Saran}

Berdasarkan kajian yang telah dilakukan, beberapa masukan yang dapat kami sampaikan, sebagai berikut:

1. Perlu meninjau kembali pemutakhiran data asumsi yang digunakan dalam membentuk rumusan model untuk memproyeksikan inflasi dengan berkoordinasi dengan Badan Pusat Statistik (BPS).

2. Pembobotan untuk merumuskan indeksasi pada masing-masing komponen

memungkinkan

dikembangkan pada metode dan proporsi komponen yang lebih tajam.

\section{DAFTAR PUSTAKA}

Ardra. 2016. Jenis-jenis, Sifat, Sebab, dan Asal Inflasi (diakses pada 13 Desember 2016 https://ardra.biz/ekonomi/ekonomimakro/jenis-sifat-sebab-dan-asalinflasi/)

Badan Pusat Statistik. 2016. Jakarta. Laman https://www.bps.go.id/

Cladi, Emha. 2012. Makalah Inflasi dan Indeks Harga. Barru. (diakses pada 13 Desember 2016 https://emhaclady.wordpress.com/ 2012/03/08/makalah-inflasi-danindeks-harga/)

Peraturan Menteri Keuangan Nomor 71/PMK.02/2013tentang Pedoman Standar Biaya, Standar Struktur Biaya, dan Indeksasi dalam Penyusunan Rencana Kerja dan Anggaran Kementerian Negara/Lembaga.

PMK Nomor 143/PMK.02/2015 tentang Petunjuk Penyusunan dan Penelaahan RKA-K/L dan Pengesahan Daftar Isian Pelaksanaan Anggaran.

Peraturan Pemerintah Nomor 90 Tahun 2010 tentang Penyusunan Rencana Kerja dan Anggaran Kementerian/Lembaga.

Trihendradi, C. 2005. SPSS 13: Step by Step Analysis Data Statistik. Andi Offset: Yogyakarta.

Undang-Undang Nomor 17 Tahun 2003 tentang Keuangan Negara. 